\title{
Liechtenstein: Assessment of Financial Sector Supervision and Regulation
}

This Assessment of Financial Sector Supervision and Regulation for Liechtenstein was prepared by a staff team of the International Monetary Fund. It is based on the information available at the time it was completed on April 4, 2007. The views expressed in this document are those of the staff team and do not necessarily reflect the views of the government of Liechtenstein or the Executive Board of the IMF.

The policy of publication of staff reports and other documents by the IMF allows for the deletion of market-sensitive information.

Copies of this report are available to the public from International Monetary Fund $\bullet$ Publication Services 700 19th Street, N.W. • Washington, D.C. 20431

Telephone: (202) 623-7430 • Telefax: (202) 623-7201

E-mail: publications@imf.org • Internet: http://www.imf.org

Price: $\$ 18.00$ a copy

\section{International Monetary Fund Washington, D.C.}



INTERNATIONAL MONETARY FUND

LIECHTENSTEIN

ASSESSMENT OF FinANCIAL SECTOR SUPERViSion AND REgUlation

\author{
Prepared by Monetary and Capital Markets Department
}

Approved by Jaime Caruana

March 21, 2008

\begin{abstract}
This report is based primarily on work undertaken during a visit to Liechtenstein in the period March 21 to April 4, 2007. The assessment team comprised Messrs. Michael Moore (head; MCM), Terence Donovan (team leader, LEG), Paul Ashin, Alain Vedrenne-Lacombe, and Ms. Gabriele Dunker (all LEG), and Mr. Michael Deasy (banking supervision expert), Ms. Tanis MacLaren (securities regulation expert), and Mr. Boudewijn Verhelst (AML/CFT expert). The key findings are as follows:
\end{abstract}

- The assessment team observed substantial progress in implementing the recommendations from the 2002 assessment following the creation of the independent Financial Markets Authority (FMA) (see Appendix I). A high level of compliance in the focused review of the Basel and IOSCO standards was noted, though some weakness was observed for insurance supervision. Onsite inspections of insurance companies were not conducted as planned and the preparation of industry guidance is delayed, both as a result of resource limitations.

- The authorities and industry continue to make progress to strengthen the anti-money laundering regime. This assessment of compliance with the revised Financial Action Task Force standard, however, identifies a number of further necessary steps to achieve better compliance. The AML/CFT legislation provides a broad framework for customer due diligence (CDD), though it falls short of the international standard on some substantive issues and a range of technical points that should be addressed as Liechtenstein implements the Third ML Directive (2005/60/EC). (See Table 1 of Appendix II for key recommendations.)

- Strategic planning will need to take account of ongoing and increasing resource requirements. The assessment team observed a generally effective capacity to conduct the current level of direct supervision (with the exception of insurance) and to carry out the indirect regulatory and AML/CFT due diligence audit activities. However, the authorities will need to undertake a review of resource requirements in light of future demands on the FMA more generally. Current resources may need to be supplemented to (i) undertake direct onsite inspections in other areas (e.g., AML/CFT due diligence); and (ii) as a result of new demands from the implementation of EU directives, particularly MiFID, Solvency II, and the Third Money Laundering Directive.

Appendix II provides the Report on the Observance of Standards and Codes (ROSC) for the FATF standard for Anti-Money Laundering and Combating the Financing of Terrorism.

Michael Moore is the main author of this AFSSR with contributions from the rest of the assessment team.

The AFSSR is a summary report on implementation of the indicated financial sector regulatory standards. It has been developed to help jurisdictions identify and remedy weaknesses in financial sector supervision and regulation. The reviews do not directly assess risks, such as those associated with asset quality, markets, or fraud, which could affect the soundness of financial systems or individual institutions. 


\section{Contents}

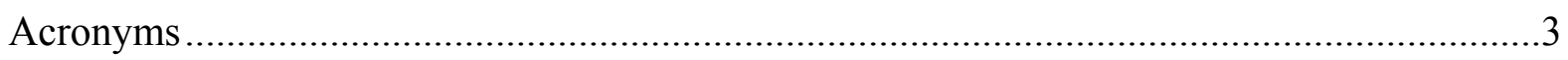

Preface

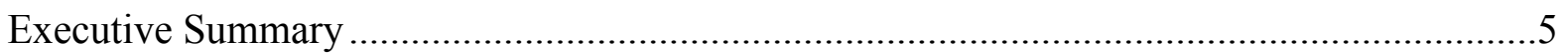

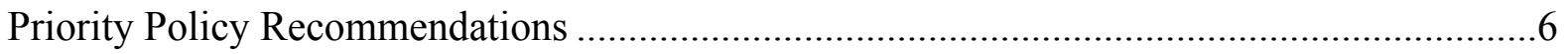

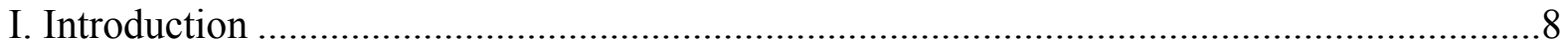

II. Financial System Overview ................................................................................. 9

A. Political and Economic Background............................................................... 9

B. Financial Sector and Regulatory Arrangements..................................................

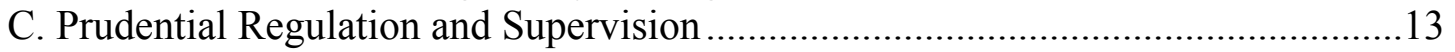

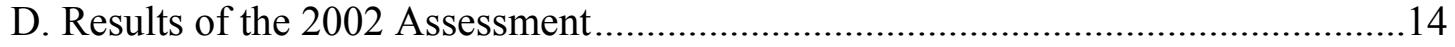

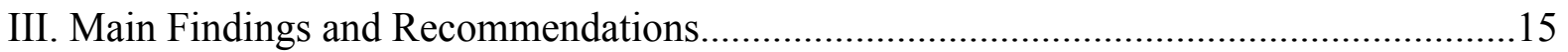

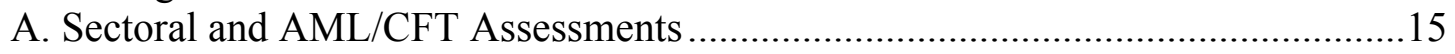

B. Cross-Sectoral Regulatory and Supervisory Issues..........................................19

Tables

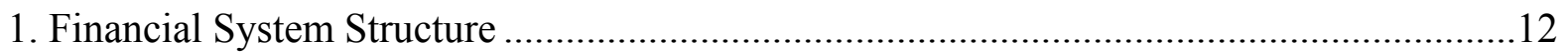

\section{Appendixes}

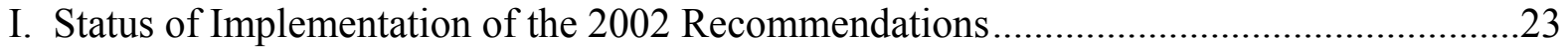

II. Report on Observance of Standards and Codes (ROSC)—FATF Recommendations........26 


\section{ACRONYMS}

AML

BCP

CESR

CFT

CDD

CRD

DDA

DDO

DNFBP

EC

EEA

EU

FATF

FIU

FMA

FSA

FT

GBOERA

IAIS

IOSCO

LEG

MCM

MiFID

ML

MLA

MONEYVAL

MOU

MVT

NCCT

$\mathrm{NPO}$

OFC

PEP

ROSC

SAR

TCSP

UCITS

UNSCR
Anti-money laundering

Basel Core Principles for Effective Banking Supervision

Committee of European Securities Regulators

Combating the financing of terrorism

Customer Due Diligence

Capital Requirement Directive (implementation of Basel II)

Due Diligence Act

Due Diligence Ordinance

Designated nonfinancial businesses and professions

European Communities

European Economic Area

European Union

Financial Action Task Force

Financial intelligence unit

Financial Markets Authority

Financial Services Authority

Financing of terrorism

Office of Land and Public Registration

International Association of Insurance Supervisors

International Organization of Securities Commissions

IMF Legal Department

IMF Monetary and Capital Markets Department

Markets in Financial Instruments Directive

Money laundering

Mutual Legal Assistance

Council of Europe Committee of Experts on the Evaluation of AntiMoney Laundering Measures

Memorandum of Understanding

Money or Value Transfer Services

Non Cooperative Countries and Territories

Non Profit Organization

Offshore Financial Center

Politically Exposed Person

Report on Observance of Standards and Codes

Suspicious activity report

Trust and Company Service Provider

Undertakings for collective investments in transferable securities

(investment funds, mutual funds)

United Nations Security Council Resolution 


\section{PREFACE}

This report presents the conclusions of the IMF assessment of observance of financial sector supervisory and regulatory standards in the context of the Module 2 offshore financial center (OFC) assessment, which visited Liechtenstein during March 21 to April 4, 2007. The mission reviewed developments in the supervisory and regulatory framework since the last Module 2 OFC assessment mission in 2002.

The mission team held extensive discussions with staff of the Financial Markets Authority (FMA), other representatives of government, and with members of industry and industry associations. Staff of the FMA and the other authorities were very generous in making themselves available for discussions, which were helpful, frank, and forthcoming. The assistance from industry representatives was also very helpful.

The assessment was based on a review of the relevant legislation, questionnaires prepared by the authorities, and publicly available information that was considered in advance of and during the mission. The relevant laws, ordinances, and most other documentation were made available to the mission team in English.

The mission team comprised Messrs. Michael Moore (head; MCM), Terence Donovan (team leader, LEG), Paul Ashin, Alain Vedrenne-Lacombe, and Ms. Gabriele Dunker (all LEG), and Messrs. Michael Deasy (banking supervision expert) and Boudewijn Verhelst (AML/CFT expert), and Ms. Tanis MacLaren (securities regulation expert).

The mission team would like to express its appreciation for the excellent cooperation of all parties consulted and the kind hospitality of the Liechtenstein authorities. 


\section{EXECUTIVE SUMMARY}

The financial sector in Liechtenstein provides primarily wealth-management services, including banking, trust, other fiduciary services, investment management, and life insurance. The industry is expanding, including in the nonbanking areas, particularly investment undertakings and insurance. The success of the financial services industry reflects in part the not insignificant role of quality supervision and regulation.

The establishment of the Financial Market Authority (FMA) as the unified, independent regulator in January 2005 was a huge step for the financial services industry. This assessment has observed the substantial progress achieved in establishing a modern supervisory and regulatory regime. The FMA's ability to share information with domestic and foreign regulatory authorities works well in practice, and the capacity and willingness to cooperate has been demonstrated in the interactions by the FMA and other authorities with their foreign counterparts.

The FMA and other authorities have been very successful in implementing most of the recommendations provided in the earlier 2002 IMF assessment. The mission team found a high standard of compliance in its focused review of the Basel Core Principles and IOSCO Principles. ${ }^{1}$ The IAIS Insurance Core Principles were not assessed; however, there appears to be a capacity constraint at the FMA for insurance supervision in light of the significant growth in the insurance sector. In this regard, and for all areas subject to FMA supervision, the authorities will need to consider the demands on the FMA to ensure that it is able to sustain quality supervision. This assessment recommends that there be an increased capacity by the FMA to conduct onsite inspections of regulated firms. The development of this increased capacity, along with the demands to implement the EU requirements will mean that resources will need to be kept under review to ensure sufficiency, and augmented as necessary.

The authorities and the industry continue to make significant efforts to strengthen the anti-money laundering regime, though there is still work ahead. There have been substantial improvements since 2002, particularly in ensuring that there is a high awareness by the financial services industry to prevent misuse of the financial system. The IMF's earlier assessment recognized the progress that had been made as measured against the earlier Financial Action Task Force (FATF) anti-money laundering standard. This assessment of compliance, which is against the now more rigorous FATF standard, identifies a number of further necessary steps to achieve a higher level of compliance (see item 5 of the Priority Policy Recommendations).

\footnotetext{
${ }^{1}$ Under current policies, partial assessments of financial sector standards (e.g., BCP and IOSCO) do not result in issuance of a formal Report of Observance of Standards and Codes.
} 


\section{Priority Policy Recommendations}

\section{Financial Markets Authority}

- Follow through with the strategic plan to consider future resource requirements for on-site supervision and the future demands from implementation of EU Directives.

- A formal process should be agreed to ensure that a suitable alternative Board member can act in the event of an extended absence by any Board member.

\section{Banking (Basel Core Principles)}

- Review resources to ensure that they remain sufficient in light of the developing nature of banking supervision and increasing EU requirements, particularly the Capital Requirement Directive (CRD) and Markets in Financial Instruments Directive (MiFID).

- Amend guidance to external auditors to include specific requirements for the Capital Requirement Directive (i.e., Basel II).

\section{Securities (IOSCO Principles)}

- Priority should be given to the development of appropriate guidance for auditors in performing the regulatory audits of asset managers.

- Principles for Market Intermediaries:

- Provide the names of authorized personnel on the website listing of authorized firms.

- Introduce an affirmative obligation on the part of an asset manager to give prompt notice to the FMA, if it becomes undercapitalized.

- Implement fully all parts of the Asset Management Act; in particular, the Code of Conduct should be finalized.

- Ensure that compliance with the MiFID investor protection requirements is reviewed during the regulatory audit performed on both asset managers and banks.

- Pursue membership in the Committee of European Securities Regulators (CESR) in line with EEA status. This would be as a measure to strengthen international cooperation arrangements for crossborder securities activities.

\section{Insurance (IAIS Core Principles)}

- Undertake inspections of insurers in line with expectations for direct supervision.

- Review capacity for the insurance supervision function with a view to ensuring that resources are sufficient to conduct onsite inspections and implement EU directives.

- Review reporting requirements, with a view to increasing the frequency of prudential reporting requirements to permit interim offsite analysis of the condition of firms.

- Expand the coverage of regulatory audits to include the assessment of risk-management systems. 


\section{AML/CFT}

- In line with the UN Conventions (the Palermo, Financing of Terrorism, and Vienna), fully criminalize money laundering and financing of terrorism.

- Strengthen legislative requirements for customer and beneficial ownership information, including obligations to (i) understand the ownership and control structure of legal persons; (ii) determine the natural person(s) that exercise ultimate control; (iii) perform enhanced due diligence on a broader range of potentially high-risk clients; and (iv) monitor and maintain customer information for crossborder and domestic wire transfers.

- Enhance the due-diligence audit system through greater FMA participation in onsite inspections.

- Take steps to improve the efficiency of the appeals process in relation to mutual legal assistance and extradition requests.

- To improve the effectiveness of the SAR reporting, remove the time limit on the prohibition against financial intermediaries informing clients about reports to the FIU ('tipping off'); discontinue the automatic freezing of assets on the filing of an SAR and extend the SAR requirement to include attempted transactions.

- Ensure that terrorist-related assets can be frozen also outside the context of those identified through the UNSCR 1267 process. 


\section{INTRODUCTION}

1. This report presents the findings of an IMF mission that visited Vaduz from March 21 to April 4, 2007, in the context of a Module 2 offshore financial center (OFC) assessment. In 2003, the IMF Executive Board reviewed the status of the OFC initiative and agreed that there should be periodic assessments (every four to five years) to monitor progress in the development of supervisory systems. ${ }^{2}$ Under the initiative, all assessments are voluntary.

\section{This assessment focused on developments in the supervisory and regulatory} framework since the Module 2 OFC assessment mission in 2002 (final report issued in 2003). Key tasks of this mission were (i) a full reassessment of the standard for anti-money laundering (AML) and combating the financing of terrorism (CFT), based on the revised Financial Action Task Force (FATF) 40+9 Recommendations; and (ii) a focused review of the Basel Core Principles (BCP) and the International Organization of Securities Commissions (IOSCO) Principles.

\section{The focused review of BCP and IOSCO principles considered only those} principles that were rated less than largely compliant (for the $\mathrm{BCP}$ ) or less than broadly implemented (for IOSCO principles) in the 2002 assessment mission. The BCP-focused review also considered issues related to compliance with the revised BCP standard. This mission did not review compliance with any of the Insurance Core Principles; however, the level of resources for insurance supervision was discussed, for which findings have been prepared.

4. The structure of the report is as follows. Section II provides an overview of the financial system, including a discussion of the political and economic background and financial sector and regulatory arrangements. Section III provides the main findings and recommendations according to each sector (banking, securities, and insurance) and for anti-money laundering and combating the financing of terrorism (AML/CFT). Appendix I provides the status of implementation of the 2002 recommendations, and Appendix II provides the ROSC for the assessment of compliance with the FATF Recommendations.

\footnotetext{
${ }^{2}$ See the Staff Paper Offshore Financial Centers, The Role of the IMF for a description of a Module 2 (http://www.imf.org/external/np/mae/oshore/2000/eng/role.htm); and Public Information Notice No.03/138 for a summary of the Executive Board discussion (http://www.imf.org/external/np/sec/pn/2003/pn03138.htm).
} 


\section{Financial System OvervieW}

\section{A. Political and Economic Background}

5. The principality of Liechtenstein is a monarchy with also a democratic parliamentary system. The head of state is HSH Prince Hans-Adam II. Since August 2004, Hereditary Prince Alois has exercised the sovereign powers as the representative of Prince Hans-Adam II. Government consists of a five-member cabinet nominated by parliament and appointed by the reigning prince. The parliament is comprised of 25 elected members, who serve for four years. The consent of both the reigning prince and the cabinet is needed to enact new legislation. Liechtenstein has a resident population of about 35,000, and occupies a 160 square kilometer area between Austria and Switzerland. It has a customs union and monetary union with Switzerland.

6. Real GDP in 2004 was CHF 4.3 billion, up 3.5 percent from 2003. Financial services represent 30 percent of GDP. In 2005, about 30,000 people were employed in Liechtenstein, of which 14, 500 were inward commuters from Austria and Switzerland. Employment in the financial services industry is responsible for about 15 percent of all jobs.

\section{B. Financial Sector and Regulatory Arrangements}

\section{The financial services sector offers a broad range of primarily wealth} management services, including banking, trust, other fiduciary services, investment management, and insurance to a global market with a majority of the services provided to nonresidents. The FMA was established as an integrated financial supervisory authority in January 2005. It brings together the supervisory and regulatory functions that previously were under the Financial Services Authority (FSA), the Insurance Supervisory Authority (ISA), and the Due Diligence Unit (DDU).

8. The FMA is responsible for the prudential oversight of all financial service providers, including banks, investment undertakings, asset managers, trustees, and insurance firms. It has full authority under the Financial Markets Authority Act (FMA Act) to review and grant licensing applications, prospectuses, and disclosure documents, and for carrying out supervision of all licensed entities. The FMA also has the ability to impose fines and withdraw licenses. As part of the monetary union, the Swiss National Bank performs functions of a central bank and acts as the lender of last resort and fulfils some payment systems requirements.

9. The FMA is also responsible for ensuring compliance with due-diligence requirements for purposes of anti-money laundering. Several AML/CFT laws are in effect that set out the AML/CFT requirements, as applied to the financial sector. Key laws are the Due Diligence Act (DDA) and the law concerning the Financial Intelligence Unit (the FIU Act). The FMA has a statutory obligation to inform the public prosecutor, if it suspects a crime has been committed. The public prosecutor is responsible for enforcement activity 
where there is an allegation that a crime has been committed or where the penalty sought includes imprisonment.

10. The Liechtenstein Bankers Association manages the deposit and investment insurance scheme that protects deposits of private clients up to a maximum of EUR 20,000 or the equivalent in another currency. In the event of insolvency or bankruptcy of a bank, the scheme would pay compensation to the bank's clients. The scheme is based on contributions of member banks up to a contractually agreed maximum amount assessed according to the level of deposits and investments of the member bank.

11. Liechtenstein has been a member of the European Economic Area (EEA) since 1995, which establishes the formal relationship between Liechtenstein and the European Union. As a condition of EEA membership, Liechtenstein must transpose all EEA-relevant laws of the EU in the financial services sector into domestic law. The EEA membership provides Liechtenstein's financial intermediaries with the freedom of establishment and movement of services when offering cross-border financial services within the EEA. Countries within the EEA have the same rights within Liechtenstein.

12. Under the EEA requirement, Liechtenstein has recently implemented the UCITS III Directive and the Market Abuse Directive. It is in the process of finalizing requirements of the Markets in Financial Instruments Directive (MiFID), the Capital Requirement Directive (implementation of Basel II), the insurance Solvency II Directive, and the Third Money Laundering Directive.

13. Corporate bodies are formed under the Law on Persons and Companies 1926, as amended, known as the PGR Code. Trust enterprises are formed under the Law Concerning the Trust Enterprise 1928. A variety of legal entities may be formed. The most commonly used are Company Limited by Shares, Limited Liability Company, The Establishment (Anstalt), The Foundation (Stiftung), and the Trust Enterprise.

\section{The banking sector}

14. The banking sector is regulated under the Law on Banks and Finance Companies of 1992 (the Banking Act). The last amendment was in 2006, with a further revision underway to implement the new European Union Directives for Basel II and Markets in Financial Instruments. The main activity of all of the banks is asset management (private banking).

15. Liechtenstein has 15 active banks with 1 additional bank in liquidation; balance sheet assets were CHF 48 billion and client assets under management of CHF 173 billion at end-2006. Eight banks are controlled by Liechtenstein-domiciled investors, four are 
controlled by Swiss investors (including one bank in voluntary liquidation ${ }^{3}$ ), and four are controlled by Austrian investors. Three of the banks have operations in foreign countries, generally in the form of banks and/or investment companies.

16. The banking market is highly concentrated with the three largest banks (all controlled by Liechtenstein-domiciled investors) accounting for 90 percent of the total balance sheet assets, 86 percent of assets under management, 89 percent of operating profits, and 63 percent of employment in the banking sector. Two of the three largest banks are publicly quoted on the Swiss Stock Exchange.

\section{Securities activities}

17. Securities-related activity is primarily asset management for high-net-worth individuals. The major business is asset management—carried out by universal banks, licensed under the Banking Act, investment undertakings (collective investment schemes) licensed under the Investment Undertakings Act, and asset managers licensed under the Asset Management Act.

18. The majority of clients are located outside of Liechtenstein (the largest number are in European jurisdictions). While only one bank is a participant of the Swiss stock exchange, SWX, all banks also offer brokerage services - including the sale of investment funds and securities - to retail investors. All client assets of asset managers must be held at a depository bank and the asset manager may not have access to any of those assets.

19. The investment funds industry is growing quickly. As of December 31,2006 , there are 28 licensed fund management and investment companies and 208 investment funds with a total of CHF 26.6 billion assets under management. The equivalent figures for December 31, 2005 are 27 fund managers and investment companies and 166 funds with CHF 20.6 billion in assets. The licensing of asset managers under the Asset Management Act is still underway. There were 48 licensed asset managers in Liechtenstein, as of the end of 2006 (58 at end-March 2007), managing an estimated CHF 11.2 billion. There were an additional 33 applications pending as of end-March 2007.

\section{Insurance sector}

20. Insurance is regulated by the Law on the Supervision of Insurance Undertakings (Insurance Supervision Law) of 1995 and other laws. At end-2006, there were 35 insurance companies, of which 17 are life companies, 13 are nonlife, and 5 are reinsurance companies. Most of the Liechtenstein life companies are wholly owned subsidiaries of well known, internationally active insurance companies or banks. Only

\footnotetext{
${ }^{3}$ The liquidation is a voluntary judicial process that is also subject to the FMA's monitoring. No depositors/clients suffered losses in the course of the liquidation.
} 
two insurance companies are locally-owned. ${ }^{4}$ The insurance captive companies are affiliated with well-known industrial and pharmaceutical companies. There were a further 26 branch offices of Swiss insurance companies and one French company (11 life, and 16 non-life), and 38 Swiss and 202 EEA insurance companies are licensed for cross-border service operations in Liechtenstein.

\section{Table 1. Liechtenstein: Financial System Structure}

\begin{tabular}{|c|c|c|c|c|c|}
\hline Type of Institution & 2002 & 2003 & 2004 & 2005 & 2006 \\
\hline \multicolumn{6}{|l|}{ Banks } \\
\hline Number & 17 & 17 & 16 & 16 & 16 \\
\hline Assets (million CHF) & 35,832 & 38,354 & 36,750 & 42,336 & 48,190 \\
\hline Loans (million CHF) & 26,815 & 28,289 & 27,341 & 30,554 & n.a. \\
\hline Deposits (million CHF) & 25,675 & 28,494 & 26,663 & 29,769 & n.a. \\
\hline Tier 1 Capital (million CHF) & 4,227 & 4,217 & 4,558 & 5,107 & 5,192 \\
\hline Net Income (million CHF) & 214 & 376 & 426 & 601 & 710 \\
\hline Asset under management (million CHF) & 106,500 & 116,793 & 119,374 & 148,667 & 173,388 \\
\hline Return on assets (average) (in percent) & 0.6 & 1 & 1.2 & 1.4 & 1.5 \\
\hline \multicolumn{6}{|l|}{ Asset Management Companies } \\
\hline Number & n.a. & n.a. & n.a. & n.a. & 48 \\
\hline Total assets (million CHF) & n.a. & n.a. & n.a. & n.a. & 11,200 \\
\hline \multicolumn{6}{|l|}{ Investment Funds } \\
\hline $\begin{array}{l}\text { Number } \\
\text { Total assets (million CHF) (Mutual }\end{array}$ & 90 & 107 & 141 & 163 & 208 \\
\hline Funds) & 6,100 & 11,980 & 15,610 & 20,570 & 26,655 \\
\hline \multicolumn{6}{|l|}{ Insurance } \\
\hline Number of life insurance firms & 12 & 12 & 15 & 17 & 17 \\
\hline Premium income (million CHF) & n.a. & n.a. & 2355 & 4025 & 6563 \\
\hline Number of non-life firms & 5 & 6 & 7 & 9 & 13 \\
\hline Premium income (million CHF) & n.a. & n.a. & 159.6 & 126.03 & 165.58 \\
\hline Number of reinsurance firms & 4 & 5 & 6 & 5 & 5 \\
\hline \multicolumn{6}{|l|}{ Trustees } \\
\hline Number (natural persons/legal entities) & $81 / 277$ & $99 / 287$ & $105 / 293$ & $113 / 308$ & $111 / 292$ \\
\hline
\end{tabular}

Source: Financial Markets Authority

\footnotetext{
${ }^{4}$ The largest Liechtenstein company, CapitalLaben, has recently agreed to merge with Swiss Life.
} 
21. The insurance activity is growing, with the recent experience of about two to three new insurance companies entering the market per year (including captives). In 2006, the aggregate gross premiums for all insurance undertakings were CHF 6.8 billion, up from CHF 4.2 billion in 2005. Assets were CHF 16.8 billion at end 2006, up from CHF 10.7 billion in 2005.

22. Life insurance companies account for more than 90 percent of aggregate premium and insurance company assets. Ranked by premium income, most clients are from Germany, followed by Austria, Belgium, Italy, Sweden, and Switzerland. The main life insurance product is unit-linked life insurance, accounting for more than 85 percent of insurance company assets. The unit-linked life insurance product, though providing some insurance, is primarily an investment product, with the payout dependent on the performance of the investment.

\section{Prudential Regulation and Supervision}

23. The Financial Markets Authority (FMA) is the supervisory authority responsible for banking supervision, securities regulation, insurance supervision, and anti-money laundering due diligence for financial and nonfinancial businesses. The tasks and powers of the FMA are set out in the Financial Market Authority Act of 2005 (the FMA Act), with additional tasks and powers set out in other acts that apply to key financial sectors.

\section{The FMA is an independent authority operating as an autonomous institution} under the FMA Act. The FMA has its own legal personality under public law; it is independent of the government and is exclusively accountable to the parliament. The FMA has a five-member Board, whose members have a term of office of five years. The FMA Act sets out that the FMA Board shall appoint a general management team of at least three persons. All members of the general management shall hold full-time positions. The funding for the FMA is through a budget authorization provided each year by the Liechtenstein parliament, which includes split funding from the state and from fees charged to industry. In 2006, the budget was CHF 6.6 million, with 60 percent provided by the state and 40 percent from fees; in 2007, the budget was CHF 7.3 million, with 54 percent provided by the state and 46 percent provided by fees.

25. Supervision for financial services is mainly based on a dual system of reliance on the direct onsite inspections by external auditors and augmented by offsite indirect supervision by FMA staff. For the indirect supervision, the FMA relies on the review of the audit reports and periodic prudential reports. For insurance supervision, the FMA also relies on external actuaries for certain reporting requirements. The FMA additionally has a program of limited direct onsite inspections and can direct external auditors to work on its behalf. 
26. The FMA sets out the detailed provisions on the content of the regulatory audit and actuarial reports through specific ordinances to the relevant financial sector laws. These reports are submitted simultaneously to the Board of Directors of the regulated institution, and the FMA pursuant to the provisions of the Law on Persons and Companies, and the FMA Act.

27. The auditors under the legislation must verify that (i) the business activities conform to the law, the articles of association, and the rules and regulations; (ii) the preconditions for granting the license are continuously met; and (iii) the form and content of the business report and the consolidated business report conform to the requirements of the law, articles of association, and rules and regulations.

\section{Results of the 2002 Assessment}

28. The 2002 assessment mission reviewed the level of compliance with four standards: Basel Core Principles, IOSCO Principles, IAIS Insurance Principles, and the FATF Recommendations on AML/CFT. Detailed assessments and ROSCs were prepared for the four standards, which the authorities agreed to publish. ${ }^{5}$

29. The 2002 assessment concluded that resources were not sufficient to conduct supervision and regulatory functions for banking, securities, and insurance activities. Resources were not sufficient to effectively use the work of the auditors, nor the regulatory reporting for off-site supervision and monitoring. The mission also sought clarification in several areas; notably, operational and credit risks, rules for external auditors, and remedial actions. For the BCP, there were five principles considered materially noncompliant and for the IOSCO principles, there were seven principles considered partly implemented.

30. The earlier mission observed a high level of compliance with the FATF standard that was in effect at the time (based on the 1996 version and 2002 methodology). The team observed a heightened commitment to AML/CFT efforts in large part due to the FATF's adverse listing of Liechtenstein as a noncooperative country in the fight against money laundering in 2000. Following significant strengthening measures by the authorities and the industry, the FATF observed progress in addressing earlier identified deficiencies

\footnotetext{
${ }^{5}$ The earlier report (Volumes 1 and 2) are available on the IMF's website at Assessment of the Supervision and Regulation of the Financial Sector Volume I-Review of Financial Sector Regulation and Supervision and Assessment of the Supervision and Regulation of the Financial Sector Volume II-Detailed Assessment of Observance of Standards and Codes.
} 
and, subsequently, removed Liechtenstein from its list of noncooperative countries or territories in June 2001 and ceased further monitoring in June 2002.

\section{MAin FIndings AND RECOMMENDATIONS}

\section{A. Sectoral and AML/CFT Assessments}

31. There has been substantial progress in implementing the recommendations from the $\mathbf{2 0 0 2}$ assessment in various areas of financial sector regulation (see Appendix 1).

Key to this progress was the creation of the FMA as an independent agency formed under the FMA Act, with a full range of regulatory powers and resources that appear largely adequate to carry out its current level of activities. It is accountable directly to parliament and the annual report is published on the FMA's website. The consultation process for formulation of new provisions is open and the FMA's relationship with the industry is constructive.

32. Strategic planning should consider future resource requirements. With the exception of insurance supervision, the mission team observed an effective capacity to conduct the current level of direct supervision, and to ensure adequacy of the indirect regulatory and due diligence audit activities. The mission team takes note of the pending additions to staff to implement Basel II and other initiatives being taken for banking supervision. The mission team supports the efforts underway in the preparation of a longer range strategic plan that will consider future demands on the FMA.

33. The strategy should take due account of requirements for insurance supervision and future demands on the FMA more generally from the implementation of EU Directives. The FMA did not achieve the onsite inspections of insurance companies, as was projected in 2002, and the preparation of industry guidance is delayed, both as a result of resource limitations. Furthermore, current resources may need to be supplemented to (i) undertake direct onsite inspections in other areas (e.g., due diligence); and (ii) as a result of new demands from the implementation of EU directives, particularly MiFID, Solvency II, and the Third Money Laundering Directive.

34. The following sub-sections provide other findings according to specific sectors and in regards to the review of anti-money laundering.

\section{Banking (Basel Core Principles)}

35. Compared to the situation in $\mathbf{2 0 0 2}$, there has been a very significant improvement in resources, both in terms of numbers and expertise. Five professionals, one professional trainee, and an administrative assistant are currently employed in the Banking Supervision Division. Contracts have been signed for two more professionals, both of whom have specific Basel II experience. All of this, taken in conjunction with the role of external auditors in carrying out annual regulatory audits of the banks, appears sufficient to supervise the banking system properly. However, it is vital that these resources be reviewed 
to ensure sufficiency in the light of the developing nature of banking supervision, increased volume, compound instruments, and growing EU-requirements, particularly Basel II and MiFID.

36. Guidance on operational and legal risk was incorporated in the Banking Ordinance in $\mathbf{2 0 0 4}$ and has been enhanced by the relevant provisions in the Capital Requirement Ordinance 2006 which implements Basel II in Liechtenstein. The FMA has put significant resources into the implementation of Basel II. Extensive consultation was also held with the industry. The main implementation legislation - the Capital Requirement Ordinance — was passed in December 2006 and became effective on January 1, 2007. A similar procedure was followed for the EU Markets in Financial Instruments Directive (MiFID), which will have significant implications for the investment activities of banks in Liechtenstein.

37. The focused review of the Basel Core Principles (BCPs) considered only those Principles that were rated at "materially noncompliant" or lower, during the 2002 Assessment. There were five such ratings - all rated as materially noncompliant. Four related to lack of resources within the regulator and the fifth to lack of guidance by the regulator on operational and legal risk. There have been very substantial improvements in all cases.

38. The assessment also reviewed preparedness for adoption of the revised BCP standard. While this review was necessarily limited by time, it appears that the FMA would do well generally in meeting the requirements for compliance, particularly in the context of compliance with the requirements of Basel II. The revised principles deal to a large extent with enhanced risk management processes and include specific principles to deal with liquidity and interest rate risk. Basel II is also very much concerned with increased risk management and has specific sections dealing with liquidity and interest rate risk. The ability to meet the revised principles is also influenced by the relatively uncomplicated nature of banking business in Liechtenstein, i.e., private banking and small and straight-forward lending practices.

\section{Securities activities (IOSCO Principles)}

39. The FMA has clear power to license, supervise, and take appropriate enforcement actions against banks, investment undertakings, and asset managers. In particular, it recently was given express authority over asset management activities via the Asset Management Act. It may make legally binding rules. Its resources and funding are stable and appear to be reasonable to support its current activities with respect to securities markets participants. Additional funding may be required if demands from EU directives and other initiatives increase. The staff are highly educated and continuous training is a priority. All staff have gained significant expertise since the last assessment and many of the added staff have direct experience in relevant industries. 
40. The gaps in the regulator's authority noted in the 2002 assessment have been filled. The FMA has full inspection and enforcement powers over banks, investment undertakings and asset managers, and these powers are used effectively for banks and investment undertakings. Under the dual system of supervision in place, regular inspections of all banks, investment undertakings, and asset managers are conducted by the appointed external auditor. Direct on-site reviews of banks and investment undertakings by the FMA have taken place. The full implementation of the Asset Management Act is at an early stage and so there is very little experience in that area. Given the expertise and processes in place for the other sectors, it is reasonable to expect a similar level of effectiveness here.

\section{Asset managers are now licensed and supervised separately from trustees, as}

recommended. Asset management is a separate licensable activity and appropriate minimum entry standards, such as fit and proper assessments and minimum capital requirements, now apply both to banks and asset managers. Authorized firms are listed on the FMA's website, which could be supplemented by including the names of the authorized personnel. There should be an affirmative obligation on the part of an asset manager to give prompt notice to the FMA if it becomes undercapitalized. Priority should be given to full implementation of the Asset Management Act.

42. Both banks and asset managers are subject to requirements designed to ensure investor protection and prudent risk management. The internal control and risk management guidance applicable to banks is extensive, while the requirements set out for asset managers are more general. This reasonably reflects the lesser risk of the latter business in the jurisdiction. MiFID will impose extensive investor protection requirements on both types of regulated firms when it is fully implemented in late 2007. The FMA should update the guidance provided to auditors to ensure compliance with MiFID standards is reviewed in detail during regulatory audits of intermediaries.

\section{Insurance (Insurance Core Principles)}

\section{The insurance sector, primarily life insurance, is rapidly expanding as an} important segment of financial services activities. At end-2006, assets for insurance undertakings were CHF 16.8 billion, which was an increase of 57 percent over the prior year, due largely to growth in unit-linked life insurance. To date, the FMA has focused its efforts on ensuring that the companies entering the Liechtenstein market are owned and controlled by strong internationally respected financial institutions.

\section{The FMA has limited capacity to undertake onsite inspections in the insurance} sector. In 2002, there was one material concern noted in the assessment that considered the lack of capacity of the supervisor to undertake onsite inspections. ${ }^{6}$ Since 2002 , the authorities

\footnotetext{
${ }^{6}$ In light of the few material concerns expressed in the 2002 IAIS Core Principles Assessment, the mission team did not undertake an update of the 2002 assessment during this visit.
} 
indicate that onsite inspection activity has remained limited, with only one comprehensive inspection conducted in 2006. The follow-through from that assessment was less than had been projected by the authorities in their response to the 2002 assessment. ${ }^{7}$

45. Staffing since the $\mathbf{2 0 0 2}$ assessment has increased from seven to nine staff, and two additional trainees began in March 2007. The authorities will need to review existing staffing levels with a view to ensuring that resources should allow a systematic program of on-site inspections. In particular, there has not been sufficient comprehensive review from a prudential perspective of the high growth areas to determine whether risk-management systems are adequate. Consideration could be given to further augmenting the onsite inspections by expanding the coverage of checks carried out on behalf of the FMA by the external auditors. In particular, the regulatory audits could be expanded to coverage of riskmanagement systems.

\section{Anti-Money Laundering and Combating the Financing of Terrorism (FATF Recommendations)}

46. This assessment recognized the serious and significant efforts to improve the AML/CFT regime for which further strengthening is recommended, particularly to reflect fully the provisions of the revised FATF standard and Third EU Money Laundering Directive. The revisions to the Due Diligence Act (DDA) in 2005 and related measures address many aspects of the revised FATF Recommendations, though, in some cases, the measures lack necessary precision.

\section{Money laundering and financing of terrorism are not fully criminalized} according to the relevant UN Conventions (the Palermo, Financing of Terrorism, and Vienna Conventions). UN Resolution 1267 has been implemented; however, UN Resolution 1373 requires that a procedure be developed. Mutual legal assistance and extradition requests are processed in a constructive manner, but can still be subject to many levels of appeal. A disclosure or declaration system to detect the physical cross-border transportation of currency and bearer-negotiable instruments related to money laundering or terrorist financing should be put into place.

\section{The FMA oversees the AML/CFT supervision conducted onsite by external} auditors. In this regard, the mission team recommends that there be additional participation by the FMA in direct AML/CFT onsite inspections, which could impose a need for additional resources. Nevertheless, supervision through the FMA is robust and professional, if indirect.

\footnotetext{
${ }^{7}$ The 2002 assessment noted that the supervisor had conducted a few limited-scope onsite inspections; however, the onsite inspections had lacked comprehensive coverage. The authorities indicated that, depending on available staff, the supervisor would perform systematic onsite inspections for 2003.
} 
49. Banks and other financial institutions base risk monitoring on customer profiles, facilitating identification of unusual financial activity. Some concerns remain regarding the identification of all beneficial owners, reliance on due diligence conducted by third parties, and discretion allowed in applying enhanced due diligence measures for higher-risk customers. The vast majority of designated nonfinancial businesses and professions (DNFBPs) - especially the core trust and company service providers - have been brought under the revised DDA and appear committed to compliance. They are required to perform CDD, monitor client relationships, and submit suspicious activity reports. Their reported customer due diligence and transaction monitoring practice appears satisfactory.

50. Liechtenstein's framework for ascertaining the beneficial ownership of legal entities, trusts, and arrangements needs to be strengthened. It is not always clear that implementation extends to identifying the natural persons who are the ultimate beneficial owners. In addition, the verification of identification data is too limited.

51. The Financial Intelligence Unit is performing well. The quality of suspicious activity reports by financial institutions to the FIU appears to be high; however, the level of reporting appears low. Similarly, the reporting by DNFBPs appears low compared to the number of companies formed and transactions monitored.

\section{B. Cross-Sectoral Regulatory and Supervisory Issues}

\section{Structure and independence of the Financial Market Authority}

52. The respective responsibilities of the Board and general management are set out in the statute in line with good corporate governance practices. The Board is responsible for strategic and policy-level decisions for the FMA, for hiring and supervising general management, reviewing and approving the annual report, issuing binding rules and guidance, and entering into agreements with other supervisory authorities. The general management has operational responsibility.

53. Under the FMA Act, Board members and general management must have an impeccable reputation, a high level of expertise, and practical experience in the financial services industry or supervision. None may serve in the government, parliament, or a court. Board members are appointed by parliament for five-year terms which may be renewed. Board members and general management may only be removed for specified reasons including bankruptcy, criminal conviction, lasting inability to act, or a gross breach of duty.

54. There is a high quorum requirement that is effective in ensuring independence. The Board consists of five members, a majority of whom (the chairman, deputy chairman, and one other member) must be independent of the regulated industry; therefore, no more than two members may be associated with regulated firms. Only the chairman is a full-time executive appointee. A quorum for any meeting is four members and, on any tie vote, the 
chairman has a casting vote. In practice, industry-related members cannot alone determine decisions of the Board.

55. With such a small number of Board members, however, an extended absence of any Board member may impede the work of the FMA. The mission team recommends that a formal process be agreed for ensuring that a suitable alternative Board member can act in the event of an extended absence by any Board member. As an example, the CEO of the regulator could be assigned a formal ex officio status for participation in all Board meetings, and would assume voting powers in the event of an extended absence of a regular Board member.

\section{Cooperation and information exchange}

56. The FMA has the ability to share information with domestic and foreign regulatory authorities and does so in practice. The FMA may share any information with domestic counterparts. The specific laws on banking, investment undertakings, asset management, and insurance grant the FMA the ability to share information with foreign regulators (within or outside the EEA) on the respective regulated entities licensed by the FMA that the foreign authority needs to carry out its supervisory responsibilities. This information generally is subject to confidentiality provisions and may only be passed to third parties or otherwise disclosed with the express permission of the FMA.

57. The FMA's ability to cooperate is enhanced by active participation in several relevant international organizations. The FMA representatives regularly attend the Committee of European Banking Supervisors (CEBS), Committee of European Insurance and Occupational Pensions Supervisors (CEIOPS), and the Council of Europe Committee of Experts on the Evaluation of Anti-Money Laundering Measures (MONEYVAL). However, the FMA has been unsuccessful in its efforts to join the Committee of European Securities Regulators (CESR). In light of the February 2007 introduction into force of the Market Abuse Act, membership in CESR should be pursued, particularly as Liechtenstein is an EEA member with significant cross-border financial services. The inability to participate in CESR weakens the quality of communication with European regulatory counterparts.

58. The process for sharing client-specific information has several steps, but apparently works comparatively efficiently in practice. The ability of the FMA to obtain client-related information from its regulated firms is unfettered. Its ability to share client-related information with competent foreign authorities is subject to a process, common across the legislation administered by the FMA, whereby the FMA must issue a formal order to the regulated firm stating what information is sought and that the FMA proposes to pass this information to the foreign regulator. Outside the context of a market-abuse case, this order may be appealed within 14 days to the FMA Complaints Commission, an independent tribunal established under the FMA Act. A decision of the Complaints Commission may then be appealed within 14 days to the Superior Administrative Court. 
59. A 2003 decision of the Superior Administrative Court confirmed the regulator had the ability to share client specific information with foreign regulators. The court set down the four principles that had to be met for such disclosure. ${ }^{8}$ These principles would be binding on the Complaints Commission. Use of institution or client-related information for judicial or administrative enforcement proceedings, even if this entails public disclosure, is now specifically permitted under Article 36 of the Banking Act.

60. The advent of the Market Abuse Act (implemented by Liechtenstein as a result of the EU Market Abuse Directive) has introduced further refinements to the sharing of client information regarding market-abuse offenses. The Market Abuse Act still requires the FMA to issue an order to the regulated entity regarding the proposed information sharing, but only one appeal is available directly to the Superior Administrative Court, which can only be exercised within 14 days of the FMA order. Further, the statute requires the appeal to be conducted rapidly. The only statutory grounds for refusing requests are those permitted under the EU directive, and which appear in equivalent legislation of other EU countries. Liechtenstein took the EU directive one step further and extended this statutory right to competent authorities in non-EEA member states. The only additional conditions that must be fulfilled by these other authorities is that the information must only be used for market abuse matters and must be given equivalent confidentiality to that applied by the FMA, but may be disclosed as required for a public prosecution of a market-abuse offense. In that context, the information may be passed to a third-party regulator in the foreign jurisdiction without the specific prior permission of the FMA. All in all, the Liechtenstein regime for sharing information, including the right to appeal, is fully in line with the current IOSCO standards, in particular the IOSCO MMoU.

61. In order to enhance consistency and efficiency, the FMA is discussing entering into information-sharing arrangements with the Swiss and Austrian authorities and has designated personnel to handle all information requests. The FMA has the power to enter into information-sharing agreements with foreign counterparts, but is not yet a party to an agreement. Although a lack of formal agreement is not necessarily an impediment to sharing information; it can be helpful as each request would not have to be evaluated individually.

\section{With the introduction of the MLA Act in 2000 the mutual legal assistance} situation resulted in more expedient responses, which, in part, reflected heightened pressures following the $\mathbf{2 0 0 0}$ listing of Liechtenstein as a noncooperative country. The MLA request can, however, still result in lengthy procedures, particularly due to the possibility to take the case to the Constitutional Court, even after it has passed all three lower courts of instance. All information can be shared, including confidential, and deposited on

\footnotetext{
${ }^{8}$ The four principles were (a) confidentiality - the requesting authority has to be subject to equivalent confidentiality requirements; (b) specialty - the information can only be used for the supervisory purpose indicated; (c) Long-arm - the information may not be forwarded to other authorities without consent; and (d) proportionality - no information may be provided if the foreign request is minor, made in error, or appears to be a 'fishing expedition,' etc.
} 
the basis of a court order. The refusal grounds are not excessive and universally accepted, except for the fiscal exception that is still too extensively interpreted, also in the money laundering context. However, an amendment has come into force on July 27, 2007 to exclude VAT fraud from the fiscal exemption. The statistical data show that MLA requests usually receive an effective and quite extensive response.

63. The commitment to international cooperation by the FIU is evident. Refusals to cooperate are justified by legal prohibitions, particularly the exclusive fiscal nature and purpose of the request. The FIU has broad power to query relevant information from nonpublic sources, even if, in the strict sense, the international standards do not expressly impose access to financial information at the request of a foreign FIU. The FIU takes a broad view on the issue and has already shown its willingness to cooperate also in this respect. 


\section{Appendix I. Status of Implementation of the 2002 Recommendations}

\begin{tabular}{|c|c|}
\hline 2002 Observations \& Recommendations & 2007 Status of Implementation \\
\hline \multicolumn{2}{|c|}{\begin{tabular}{|c|} 
Supervisory Authority \\
\end{tabular}} \\
\hline $\begin{array}{l}\text { General drawbacks to the structure and } \\
\text { independence of the Financial Services Authority } \\
\text { (the FSA was the predecessor to the FMA) } \\
\text { The FSA would benefit from efficiencies that would } \\
\text { come through the medium-term effort to establish an } \\
\text { integrated financial service regulator. }\end{array}$ & $\begin{array}{l}\text { The FMA was established as an integrated regulator } \\
\text { with responsibility for the oversight of the financial } \\
\text { markets in Liechtenstein, including banks, asset } \\
\text { managers, insurance companies, investment } \\
\text { undertakings, lawyers, trustees, auditors, and pensions. } \\
\text { The FMA also is responsible for due diligence in } \\
\text { financial transactions. }\end{array}$ \\
\hline $\begin{array}{l}\text { The FSA's mandate should be set out more clearly in } \\
\text { the law-current provisions are sometimes vague and } \\
\text { there is no clear constitution of the agency itself. }\end{array}$ & $\begin{array}{l}\text { The FMA Act clearly sets out, in one place, the overall } \\
\text { mandate of the regulator. }\end{array}$ \\
\hline $\begin{array}{l}\text { The FSA could operate more independently and } \\
\text { should be granted authority to license and withdraw } \\
\text { licenses, levy penalties and other sanctions against } \\
\text { regulated entities without approval from government. }\end{array}$ & $\begin{array}{l}\text { The FMA is an agency independent of the government, } \\
\text { reports to Parliament and has full authority to grant and } \\
\text { withdraw licenses, supervise, and levy penalties and } \\
\text { other sanctions against regulated entities without } \\
\text { approval from government. }\end{array}$ \\
\hline $\begin{array}{l}\text { The FSA should have the ability to make legally } \\
\text { binding rules. }\end{array}$ & The FMA has authority to make legally binding rules. \\
\hline $\begin{array}{l}\text { The FSA should introduce transparency measures to } \\
\text { its work-including a more detailed annual report and } \\
\text { a website, which would assist the public in } \\
\text { understanding its function and create a more } \\
\text { accountable regulatory process. }\end{array}$ & $\begin{array}{l}\text { The FMA website contains a detailed annual report, all } \\
\text { laws, ordinances and guidelines, a complete list of all } \\
\text { authorized firms, checklists for applicants and other } \\
\text { useful information. Many of these documents are also } \\
\text { available in English }\end{array}$ \\
\hline \multicolumn{2}{|c|}{ Banking Supervision } \\
\hline $\begin{array}{l}\text { Insufficient staff resources and experience for } \\
\text { effective and comprehensive analysis of audit } \\
\text { reports and bank reporting and understanding of } \\
\text { banks' operations. } \\
\text { Recruit experienced staff, implement more training for } \\
\text { staff. }\end{array}$ & $\begin{array}{l}\text { Additional staff with experience in banking have been } \\
\text { recruited and additional training has been undertaken for } \\
\text { all staff. }\end{array}$ \\
\hline $\begin{array}{l}\text { Auditors rely on Swiss or other practices regarding } \\
\text { credit and operational risk because of gaps in law } \\
\text { FSA should formalize a complete set of rules }\end{array}$ & $\begin{array}{l}\text { The bank ordinance was amended in } 2004 \text { to provide } \\
\text { guidelines in respect of these risks. The capital } \\
\text { requirement ordinance introduced additional rules in } \\
\text { respect of weightings for capital adequacy purposes. }\end{array}$ \\
\hline $\begin{array}{l}\text { Remedial orders applied to banks are undefined } \\
\text { Create series of specific and gradual remedial } \\
\text { measures. }\end{array}$ & $\begin{array}{l}\text { The legislation now provides for a range of actions that } \\
\text { may be taken by the FMA in response to a problem at a } \\
\text { bank. A ladder of compliance has been instituted and } \\
\text { applied. }\end{array}$ \\
\hline \multicolumn{2}{|c|}{ Insurance Supervision } \\
\hline $\begin{array}{l}\text { Insufficient resources to carry out adequate on-site } \\
\text { reviews } \\
\text { Recruit experienced staff. }\end{array}$ & $\begin{array}{l}\text { The staff number has been increased from } 7 \text { experienced } \\
\text { and qualified staff in } 2002 \text { to } 9 \text {, with an additional } 2 \\
\text { trainees added in March } 2007 \text {. }\end{array}$ \\
\hline
\end{tabular}




\begin{tabular}{|l|l|}
\hline \multicolumn{1}{|c|}{ 2002 Observations \& Recommendations } & \multicolumn{1}{c|}{ 2007 Status of Implementation } \\
\hline $\begin{array}{l}\text { Inadequate guidance on assets for unit-linked } \\
\text { policies and asset-liability management }\end{array}$ & $\begin{array}{l}\text { Not yet implemented. The authorities indicate that a first } \\
\text { draft of this guidance is ready for discussion with the } \\
\text { insurance association. The guidance sets out } \\
\text { policies and asset-liability management. }\end{array}$ \\
$\begin{array}{l}\text { requirements for admissible assets, control of assets, for } \\
\text { offering investments to policyholders according to their } \\
\text { risk profiles, advice and documentation to policyholders, } \\
\text { the selection of the asset manager and the custodian } \\
\text { bank. }\end{array}$ \\
\hline
\end{tabular}

\section{Capital Markets Regulation}

\section{Insufficient staff resources and experience for effective oversight of audits of investment funds \\ Recruit staff, expand training opportunities for staff and consider foreign counterparts as a source of training.}

Asset managers with general trustee licenses operating without proper supervision

Create separate license for asset managers; FSA to have inspection power over asset managers, establish audit program for asset managers.
Additional staff has been recruited and additional training has been undertaken for all staff. Staff does detailed reviews and follows up on the audit reports and other regular reports received.

The new Law on Asset Management requires asset managers to be licensed as such by the FMA and gives the FMA the authority to license, inspect and take enforcement action against these entities. Trustees no longer may carry on asset management activities in a firm licensed as a trustee.

Asset managers are subject to both financial and regulatory audits, as are banks and investment undertakings. Both sets of audits are mainly performed by FMA licensed auditors using the dual system of supervision. The intention of the FMA is to do more direct on-site reviews in future, either alone or accompanying the external auditor.

Anti-money Laundering

Financing of terrorism is not fully covered under existing legislation.

Complete the proposals to add a new provision for financing of terrorism that includes financing of planned terrorist acts and gathering or assembling of funds for a wide range of terrorist acts
In 2003, Articles 278b-d were added to the Criminal Code with a view to criminalizing the financing of terrorism. However, the definition of terrorist organization is not fully in line with the international standard and the financing of terrorist acts (278d) does not fully meet the scope of the offense as defined in the interpretative note to SR II. The financing of individual terrorists is not criminalized.

The scope of the Due Diligence Act was extended in February 2005 to include measures aimed at the suppression of terrorist financing. 


\begin{tabular}{|c|c|}
\hline 2002 Observations \& Recommendations & 2007 Status of Implementation \\
\hline $\begin{array}{l}\text { The prohibition against tipping off after filing of } \\
\text { SARs is limited to the ten-day automatic blocking } \\
\text { after filing. Further, the automatic ten-day } \\
\text { blocking of accounts and transactions upon filing } \\
\text { of SARs is overly broad. } \\
\text { The prohibition against tipping off should not be } \\
\text { limited in time and should be permanent. The } \\
\text { automatic 10-day blocking should be replaced by } \\
\text { discretionary authority of the FIU to block accounts } \\
\text { and transactions from a period of } 48 \text { hour up to } 10 \\
\text { days, when necessary after the filing of a SAR. There } \\
\text { should be a specific administrative sanction for } \\
\text { violations of the tipping-off prohibition. }\end{array}$ & $\begin{array}{l}\text { Not implemented to date. The recommendation was } \\
\text { based on the rule in force in } 2002 \text { providing for a } \\
\text { prohibition against tipping-off for } 10 \text { days, with the } \\
\text { possibility of extension by } 20 \text { days. As part of the total } \\
\text { revision of the Due Diligence Act in February } 2005 \text {, this } \\
\text { rule was adjusted so that a prohibition against tipping- } \\
\text { off of } 20 \text { days without the possibility of extension is } \\
\text { provided for. } \\
\text { The revised Due Diligence Act introduced the possibility } \\
\text { of some flexibility in the blocking of assets. Assets } \\
\text { continue to be blocked automatically but only for a } \\
\text { maximum of five days. However, the blocking may be } \\
\text { suspended by the FIU for individual transactions. }\end{array}$ \\
\hline $\begin{array}{l}\text { The external audits for due diligence for banks are } \\
\text { currently required to be conducted separately from } \\
\text { the supervisory audits and by different auditors. } \\
\text { This framework does not capitalize on depth of } \\
\text { management and internal control information } \\
\text { available in the supervisory audit, and may result } \\
\text { in gaps of coverage. } \\
\text { The due diligence audit for banks should be conducted } \\
\text { by the same auditor that conducts the supervisory } \\
\text { audit. These audits should be conducted in a } \\
\text { coordinated manner, if not concurrently. The statutory } \\
\text { requirement for independence is sufficient to ensure } \\
\text { that audits are conducted thoroughly and without } \\
\text { undue influence. }\end{array}$ & $\begin{array}{l}\text { This recommendation was accepted and implemented in } \\
\text { the form of Article } 24.5 \text { of the Due Diligence Act, as } \\
\text { amended in February } 2005 \text {. Due diligence audits for } \\
\text { banks are now carried out on an annual basis by the } \\
\text { same auditors that carry out the supervisory audits. They } \\
\text { are conducted in a coordinated manner, if not } \\
\text { concurrently. }\end{array}$ \\
\hline $\begin{array}{l}\text { No industry guidance exists for the insurance } \\
\text { sector to identify activities vulnerable to money } \\
\text { laundering. } \\
\text { Guidelines for monitoring of accounts should be } \\
\text { amended to require special attention to single- } \\
\text { premium life and buying and selling second-hand } \\
\text { endowments }\end{array}$ & Not implemented to date. \\
\hline
\end{tabular}




\title{
Appendix II. Report on Observance of Standards and Codes (ROSC)
}

\author{
FATF Recommendations for Anti-Money Laundering and \\ Combating the Financing of Terrorism
}

\section{Prepared by the Legal Department Approved by Sean Hagan}

\begin{abstract}
A. Introduction
64. This Report on the Observance of Standards and Codes (ROSC) for the FATF 40 Recommendations for Anti-Money Laundering (AML) and 9 Special Recommendations for Combating the Financing of Terrorism (CFT) was prepared by staff of the IMF. ${ }^{9}$ The report provides a summary of the AML/CFT measures in place in Liechtenstein and of the level of compliance with the FATF Recommendations, and contains recommendations on how the system could be strengthened. The assessment was conducted using the 2004 Methodology and is based on the information available at the time it was completed on April 4, 2007. The Detailed Assessment Report on which this ROSC is based has been agreed with the Liechtenstein authorities and adopted at the MONEYVAL plenary, September 10-14, 2007. The views expressed in this document are those of the staff team and do not necessarily reflect the views of the government of Liechtenstein or the Executive Board of the IMF.
\end{abstract}

\section{B. Key Findings}

65. The financial sector in Liechtenstein provides primarily wealth-management services, including banking, trust, other fiduciary services, investment management, and life insurance products. There has been significant expansion in non-banking areas such as investment undertakings and insurance. Around 90 percent of financial services business is provided to nonresidents, many attracted by access to discrete and flexible legal structures, strict bank secrecy, and favorable tax arrangements, within a stable and well-regulated environment.

66. Due to the financial and corporate services provided, Liechtenstein's financial sector creates a particular money laundering (ML) risk against which the authorities and private sector apply risk-based mitigating measures. Minimizing the risk of abuse of corporate vehicles and related products is an ongoing challenge, as is the identification of the beneficial owners of the underlying assets or legal persons or arrangements. The vulnerability is mainly in the layering phase of ML, with no particular vulnerability noted to terrorist financing (FT).

\footnotetext{
${ }^{9}$ The evaluation team consisted of: Terence Donovan, Paul Ashin, Gabriele Dunker, and Alain VedrenneLacombe, IMF Legal Department, and Boudewijn Verhelst, consultant. Mr. Verhelst also acted as assessor for MONEYVAL to address the provisions of relevant EU Directives outside the Fund's AML/CFT mandate.
} 
67. Liechtenstein was listed by the FATF as part of its initial review of noncooperative countries and territories (NCCTs) in 2000 but was delisted in 2001. The authorities have since made significant progress in moving towards compliance with the FATF Recommendations, as already noted in the IMF's AML/CFT assessment of 2002 and as evidenced by the subsequent major legislative amendments and institutional restructuring.

68. Both ML and FT are criminalized broadly (though not fully) in line with the international standard. There is no criminal liability of corporate entities. The quality of its analysis and output indicates that the Financial Intelligence Unit (FIU) makes effective use of the information it receives. However, the effectiveness of the reporting system could be improved, including by discontinuing the requirement for automatic freezing of assets for five days following filing of suspicious activity reports (SARs).

69. Investigative powers available to the law enforcement authorities are comprehensive enough to enable them to conduct serious investigations in an effective way. However, the number of investigations and prosecutions resulting from the files forwarded by the FIU appears low. There have been consequent convictions for ML or a predicate offense, though not in Liechtenstein. The Liechtenstein prosecutors consider it more effective to refer cases to the jurisdictions where the main criminal activity is alleged to have taken place and then provide strong support to the resultant prosecution.

70. Financial institutions and relevant designated nonfinancial businesses and professions (DNFBPs) are supervised by the Financial Market Authority (FMA), which reports directly to Parliament. The AML/CFT law (Due Diligence Act-DDA) and the Due Diligence Ordinance (DDO) provide the main legal basis for the AML/CFT preventive measures. Some doubt remains as to whether the scope of AML/CFT coverage is sufficiently wide. The DDA and DDO provide a broad framework for customer due diligence (CDD), though fall short of the international standard on some substantive issues and a range of technical points. This reflects the fact that, similar to many other European Economic Area member states, Liechtenstein is in the process of implementing the Third EU ML Directive (2005/60/EC) by 2008, which provides an opportunity to address the identified deficiencies.

71. CDD requirements are based around preparing and maintaining a customer profile, including beneficial ownership, source of funds, and purpose of the relationship. Discussions with auditors, who are contracted by the FMA to conduct AML/CFT on-site supervision, indicate that levels of compliance have improved significantly, although not evenly across all institution categories. The law allows excessive discretion in identifying high-risk customers and beneficial owners, and there is no explicit requirement for enhanced due diligence.

72. National cooperation on AML/CFT is effective, and Liechtenstein's ability and willingness to cooperate internationally has improved strongly. However, the legal basis for sharing of information with foreign supervisors needs to be broadened and strengthened. 


\section{Legal Systems and Related Institutional Measures}

73. Liechtenstein's crime rate is low. The major criminal activities identified as predicate offenses for ML are economic offenses, in particular fraud, criminal breach of trust, asset misappropriation, embezzlement and fraudulent bankruptcy, corruption, and bribery.

74. ML is criminalized broadly in line with the international standard, but environmental crimes, smuggling, forgery, market manipulation, and fiscal offenses (including serious fiscal fraud) are not predicate offenses for ML. Although a conviction for a predicate offense is not required, the level of proof needed to determine that proceeds are illicit remains unclear. Liechtenstein does not yet have any jurisprudence on autonomous ML. Self-laundering is partially criminalized. Apart from conspiracy to commit ML, all ancillary offenses are criminalized. Intent may be inferred from objective factual circumstances. Criminal liability does not extend to legal persons. While FT is criminalized, the definition of the offense and, in particular of "terrorist organization" should be brought in line fully with the international standard and the financing of individual terrorists should be criminalized. There have been no prosecutions or convictions for FT.

75. Liechtenstein does not have a specific disclosure or declaration system to detect the physical cross-border transportation of currency or bearer negotiable instruments. Agreement first needs to be reached with Switzerland, as the two countries operate in a customs union.

76. With regard to seizure and confiscation, besides the conviction-based criminal forfeiture, the Liechtenstein criminal procedure also provides for the possibility of an in rem (object) forfeiture which results in an effective regime. The system focuses particularly on asset recovery, which is widely used. Confiscation of all criminal proceeds, the product of the crime, the (intended) instrumentalities, and equivalent value is broadly covered. However, in autonomous ML offenses, criminal confiscation of the assets is not formally covered, and confiscation of (intended) instrumentalities is seriously restricted. The seizure regime is similar to the confiscation system. There are appropriate legal means for tracing criminal assets or proceeds, including access to confidential account information. However, there are no overall statistics available on seizures and confiscations.

77. The freezing of terrorist assets under UNSCR 1267 is adequately addressed. There is no domestic terrorist list, but action has been taken based on foreign lists. There is no specific procedure outside that for UNSCR 1267, although the general legal processes are available.

78. The Liechtenstein FIU is an administrative and functionally-independent unit which functions effectively and produces high-quality reports. It has legal powers to collect additional information from the disclosing entity, but the powers to obtain such information from other DDA reporting entities are open to legal question. It has been successful in raising awareness and has established a relationship of trust with the reporting entities. 
79. Law enforcement in ML and FT cases rests with the Public Prosecutor and the national police and with the investigative judges who have the power to impose coercive measures. The legal framework is comprehensive enough to enable serious investigations and effective prosecutions. However, ML-related investigations and proceedings are mostly initiated by mutual legal assistance requests, as there is a general tendency to transfer the cases to the authorities of the jurisdiction where the predicate offense occurred. Although not without foundation, this practice does keep the judiciary from developing its own experience and jurisprudence in stand-alone ML prosecutions.

\section{Preventive Measures_Financial Institutions}

80. AML/CFT preventive measures are defined in the DDA, the requirements of which are expanded in secondary legislation in the DDO. The DDA was substantially updated in 2004 with the aim of transposing the revised FATF Recommendations and the Second EU ML Directive (2001/97/EC). The DDA provides for due diligence to be completed by legal and natural persons when conducting financial transactions on a professional basis. All financial institutions and, in practice, all FATF-defined transactions are covered.

81. Liechtenstein has adopted a risk-based approach based on creating and keeping updated a profile for each long-term customer. The profile includes notably beneficial ownership information, source of funds, and purpose of the relationship. Detection of suspicious activities is based on deviation from the profile on the basis of risk criteria. However, the legal provisions for the risk-based system may give excessive discretion and do not fully comply with a number of specific criteria of the FATF Recommendations.

82. Provisions regarding CDD are broadly in line with the international standard but need to be strengthened further in some areas. The DDA and the DDO grant some exemptions from identification that are inconsistent with the FATF standard. The requirements for identification of beneficial owners, as well as verification of identity, need to be broadened. Financial institutions may rely on domestic and foreign intermediaries to provide them with customer identification information and documents, but also, contrary to the FATF standard, to conduct ongoing monitoring of customers and transactions. Moreover, they can avail of legal protection from responsibility for deficiencies in CDD work of their intermediaries.

83. The DDA and DDO provide only broad instructions for determining high-risk customers, for complex, unusual large transactions or unusual patterns of transactions, or those from countries that do not or inadequately apply the FATF Recommendations, as well as for defining specific due diligence for politically-exposed persons (PEPs) or respondent banks. Records, which have to be maintained for at least 10 years, should be sufficient to permit reconstruction of individual transactions and provide evidence for prosecution. $\mathrm{AML} / \mathrm{CFT}$ requirements for foreign branches and subsidiaries need to be strengthened. 
84. The FMA, which is an independent authority, is an integrated supervisor in charge of prudential and AML/CFT supervision. All financial institutions are licensed by the FMA. The FMA has developed and implements effectively a broad range of AML/CFT preventive measures. Annual on-site due diligence examinations are carried out by external auditors under mandate of the FMA. A greater involvement of FMA staff in on-site inspection work, requiring additional resources, could improve overall effectiveness.

85. Financial institutions have defined internal instructions, implemented training programs for their staff, and designated managers responsible for compliance with the AML/CFT law and regulations. Auditors indicated that overall compliance has improved significantly, although not evenly across all categories of reporting institutions.

86. The scope of available criminal sanctions is broad and the FMA refers cases in practice to the Prosecutor. However, the proportionality and effectiveness of the sanction system are restricted by the current narrow scope of available administrative sanctions.

87. While the quality of SARs received by the FIU is high, the overall effectiveness of the reporting system could be improved. A number of factors, notably the automatic freezing for five days of funds related to a filed report, appear to be suppressing reporting to the FIU. The reporting obligation needs to be amended to cover attempted occasional transactions and all terrorist-financing cases. Protection for reporting in good faith should be broadened. The prohibition against tipping-off, currently restricted to 20 days, needs to be made unlimited in time, as also recommended in the 2002 assessment.

88. The requirements (and their implementation) for transmitting data with cross-border wire transfers need to be brought into line with the international standard. The authorities stated that measures will be applied following their adoption of EC Regulation 1781/2006.

\section{E. Preventive Measures-Designated Non-Financial Businesses and Professions}

89. Liechtenstein's DNFBPs are subject to the obligations of the DDA and supervised by the FMA in generally the same manner as are financial institutions. In particular, the very active Trust and Company Service Providers (TCSP) sector has been brought into the AML/CFT regime. Activities covered under the DDA include both the formation of a legal entity that is not commercially active in the domiciliary state and acting as an organ of such an entity, and anyone performing such activities on a professional basis must conduct CDD, file SARs, and have appropriate internal controls. Due diligence inspections for DNFBPs are conducted by auditors designated by the FMA once every three years.

90. As the AML/CFT legal framework for TCSPs is the same as for financial institutions, most of the general strengths and weaknesses of the preventive measures as noted above also apply to them. The most critical TCSP-specific issue is the exemption from full CDD requirements for work on behalf of companies that are commercially active in the state in which they are domiciled, as the FATF standard does not provide for such an exemption. 
Given that TCSPs routinely set up companies in many foreign jurisdictions, the exemption could be very substantial and difficult to administer. In practice, the preventive measures are usually followed by the TCSPs despite the available exemption.

91. Lawyers, when not acting as TCSPs, are covered by the DDA in performing financial "gatekeeper" functions as designated by the FATF standard. They enjoy appropriate legal privilege against reporting when representing clients in court proceedings. Although auditors are similarly protected, they are not licensed to manage money or accounts for clients.

92. There are currently no casinos, but if licenses are granted in the future they will be required to identify clients at the door and report suspicious activities. Real estate agents must conduct $\mathrm{CDD}$ and report suspicions concerning foreign transactions, but not for the purchase of Liechtenstein properties, which need approval of a government agency. Highvalue goods dealers, including in precious metals and stones, are covered for cash transactions above CHF25,000, which are rare.

\section{F. Legal Persons and Arrangements \& Non-Profit Organizations}

93. Liechtenstein's laws governing legal persons and arrangements are highly liberal and offer many different forms of companies and legal arrangements, including establishments (Anstalten), foundations (Stiftungen) and common-law style trusts. Most legal provisions are not mandatory and may be changed through founding deed or statute, allowing for any legal entity/arrangement to be custom tailored to the parties' needs. It is estimated that 90 percent of all companies registered in Liechtenstein are not commercially active.

94. Liechtenstein relies on its TCSPs to obtain, verify, and retain records of the beneficial ownership and control of legal persons. All legal entities and arrangements that are not commercially active have to have at least one Liechtenstein director/trustee and provide the Office of Land and Public Registration (GBOERA) with the name and address of the relevant TCSP. The GBOERA fulfils an important role in allowing the FIU and FMA to link an entity/arrangement with a specific TCSP and thus locate beneficial ownership information.

95. TCSPs must obtain from the contracting party a written statement identifying the beneficial owner. Although the law does not explicitly require TCSPs to verify such information, it appears that they usually do so. The obligation to obtain beneficial ownership information generally covers only persons who hold economic rights to a specific legal entity or arrangement but not curators, protectors, or designated third parties controlling a structure.

96. For commercially-active companies, no formal measures are in place to ensure that beneficial ownership information is obtained, verified and maintained, although it appears that such information is generally obtained in practice. Nominee directors, nominee shareholders, protectors/collators and letter of wishes are permitted under Liechtenstein law and frequently used in relation to trusts and foundations. 
97. Liechtenstein should conduct a full review of its laws concerning Non-Profit Organizations (NPOs) and conduct fuller outreach on CFT issues to this sector.

\section{G. National and International Cooperation}

98. National cooperation between the authorities on AML/CFT matters was found to be effective, and Liechtenstein's ability and willingness to cooperate internationally and share available information has improved strongly. However, the legal basis for sharing of information with foreign supervisors needs to be strengthened as it currently relies on Court decisions to overrule the legislative prohibitions. These Court decisions are related to the Banking Act and it is not clear whether they could extend also to all financial institutions and DNFBPs. Moreover, a right of appeal could result in delays in the provision of information.

99. The FIU is active in international cooperation and may exchange information and otherwise cooperate with any counterpart financial intelligence unit abroad. In so doing, the FIU can exercise all the powers vested in it under the domestic law.

100. The legal framework of the mutual legal assistance and extradition system is basically sound and the authorities cooperate to bring proceedings to a satisfactory result. The significant scope for appeal is a delaying factor that is used in some cases. The fiscal exception is also extensively interpreted: serious and organized fraud by way of fiscal means still profits from the amnesty Liechtenstein provides for fiscal offenses. ${ }^{10}$

Table 1. Prioritized Key Recommendations to Improve the AML/CFT System

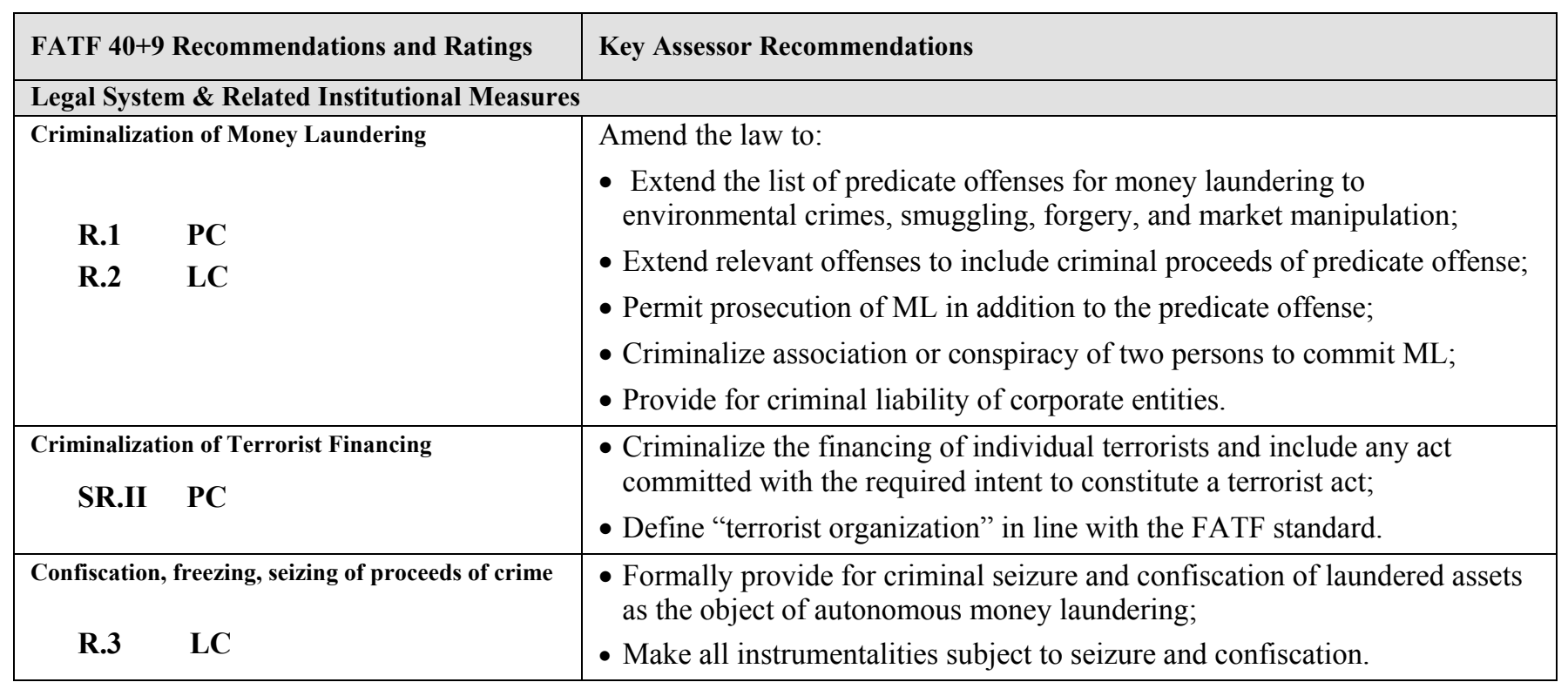

\footnotetext{
${ }^{10}$ A legislative amendment subsequent to the assessment partially remedied this situation.
} 


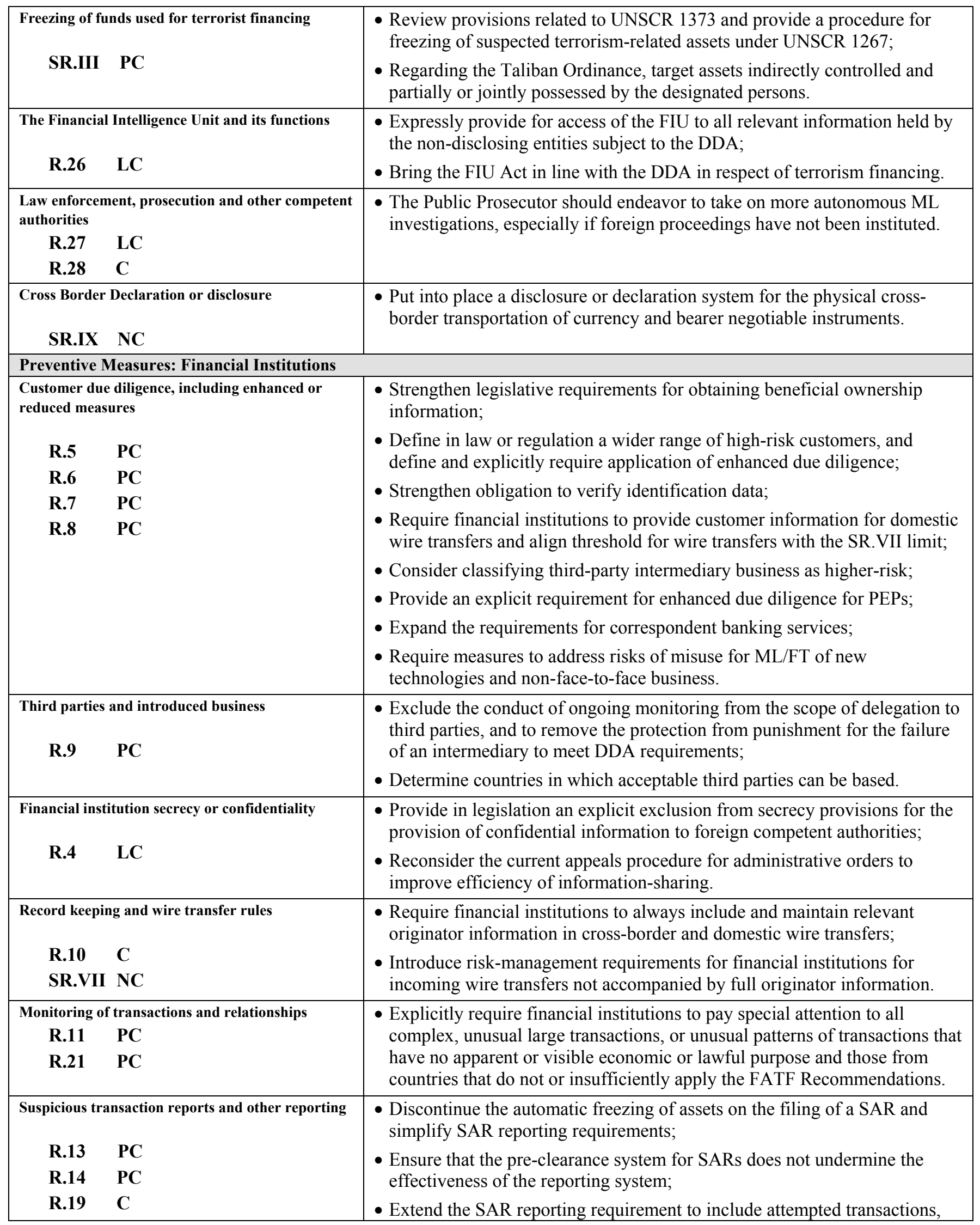




\begin{tabular}{|c|c|c|}
\hline $\begin{array}{l}\text { R.25 } \\
\text { SR.IV }\end{array}$ & $\begin{array}{l}\text { LC } \\
\text { PC }\end{array}$ & $\begin{array}{l}\text { and explicitly include funds linked or related to, or to be used for terrorism, } \\
\text { terrorist acts or by terrorist organizations; } \\
\text { - Extend good-faith reporting protection to directors, officers and employees; } \\
\text { - Remove the time limit on the prohibition of tipping off. }\end{array}$ \\
\hline $\begin{array}{l}\text { Internal contr } \\
\text { branches } \\
\text { R.15 } \\
\text { R.22 }\end{array}$ & $\begin{array}{l}\text { ols, compliance, audit and foreign } \\
\text { LC } \\
\text { PC }\end{array}$ & $\begin{array}{l}\text { - Require financial institutions to ensure that: } \\
\text { - adequate screening when hiring employees; } \\
\text { - their internal audit function is adequately resourced; } \\
\text { - foreign branches and subsidiaries observe AML/CFT measures. } \\
\text { - The FMA should take steps to improve implementation of appropriate } \\
\text { group-wide AML/CFT measures for Liechtenstein financial institutions. }\end{array}$ \\
\hline $\begin{array}{l}\text { Shell banks } \\
\text { R.18 }\end{array}$ & $\mathbf{L C}$ & $\begin{array}{l}\text { - Require on licensing that banks must engage in substantive business } \\
\text { activities or, alternatively, opt to explicitly prohibit shell banks. }\end{array}$ \\
\hline \multicolumn{2}{|c|}{ Money and value transfer services } & $\begin{array}{l}\text { - Reduce the legal threshold for MVT CDD to conform to the FATF wire- } \\
\text { transfer threshold. }\end{array}$ \\
\hline \multicolumn{3}{|c|}{ Preventive Measures: Non-Financial Businesses and Professions } \\
\hline Customer due & diligence and record-keeping & $\begin{array}{l}\text { - Strengthen legislative requirements for company formation: TCSPs should } \\
\text { conduct CDD and ascertain the beneficial owner when forming } \\
\text { commercially-active entities and related holding companies; } \\
\text { - Define in law or regulation a wider range of high-risk customers to include } \\
\text { notably non-resident accounts, accounts opened through an intermediary, } \\
\text { entities with bearer shares, trusts and foundations, and entities registered in } \\
\text { privately managed registers and databases; } \\
\text { - Apply also to DNFBPs all appropriate recommendations listed above for } \\
\text { financial institutions. }\end{array}$ \\
\hline Suspicious tra & nsaction reporting & $\begin{array}{l}\text { - Conduct outreach to non-reporting TCSPs and take other appropriate } \\
\text { measures to increase the breadth of DNFBP reporting. } \\
\text { - Apply also to DNFBPs all appropriate recommendations listed above for } \\
\text { financial institutions. }\end{array}$ \\
\hline $\begin{array}{c}\text { Regulation, st } \\
\text { R.17 } \\
\text { R.24 }\end{array}$ & $\begin{array}{l}\text { pervision, monitoring, and sanctions } \\
\text { PC } \\
\text { LC }\end{array}$ & $\begin{array}{l}\text { - Consider increasing the frequency of DDA audits for TCSPs, and a more } \\
\text { direct involvement of FMA staff in DDA audits. }\end{array}$ \\
\hline Other DNFBPs & C & - \\
\hline \multicolumn{3}{|c|}{ Legal Persons and Arrangements \& Nonprofit Organizations } \\
\hline $\begin{array}{l}\text { Legal Persons } \\
\text { beneficial owı }\end{array}$ & $\begin{array}{l}\text { and Arrangements: Access to } \\
\text { ership and control information }\end{array}$ & $\begin{array}{l}\text { - Bring the definition of "beneficial owner" in line with the FATF standard } \\
\text { to cover the control structure of legal persons and arrangements; } \\
\text { - Require intermediaries to verify beneficial ownership information; } \\
\text { - Require that information on beneficial ownership and control of legal } \\
\text { entities that are commercially active in the domiciliary state are obtained. }\end{array}$ \\
\hline
\end{tabular}




\begin{tabular}{|c|c|c|}
\hline \multicolumn{2}{|c|}{$\begin{array}{l}\text { Nonprofit organizations } \\
\text { SR.VIII PC }\end{array}$} & $\begin{array}{l}\text { - Review NPO laws and regulations and conduct outreach to NPO sector on } \\
\text { FT risks. }\end{array}$ \\
\hline \multicolumn{3}{|c|}{ National \& International Cooperation } \\
\hline \multicolumn{2}{|c|}{ National Cooperation and Coordination } & - \\
\hline $\begin{array}{l}\text { The Conventi } \\
\text { R.35 } \\
\text { SR.I }\end{array}$ & $\begin{array}{l}\text { ons and UN Special Resolutions } \\
\text { PC } \\
\text { PC }\end{array}$ & $\begin{array}{l}\text { - Ensure that the Vienna and Palermo Conventions, and the UN Convention } \\
\text { for the Suppression of Financing of Terrorism are fully implemented; } \\
\text { - Implementation of UNSCRs needs to be refined to expressly cover assets } \\
\text { under indirect control or ownership of terrorists and to fully criminalize FT. }\end{array}$ \\
\hline $\begin{array}{l}\text { Mutual Legal } \\
\text { R.36 } \\
\text { R.37 } \\
\text { R.38 } \\
\text { R.39 } \\
\text { SR.V }\end{array}$ & Assistance \& Extradition & $\begin{array}{l}\text { - The legislator should endeavor to find a solution for potential usage of } \\
\text { delaying tactics before the Constitutional Court; } \\
\text { - Serious and organized fiscal fraud should be excluded from the fiscal } \\
\text { exemption; } \\
\text { - The deficiencies in the ML and FT offense should be remedied to enable } \\
\text { full compliance with dual criminality ruled requests. }\end{array}$ \\
\hline $\begin{array}{l}\text { Other Forms } \\
\quad \text { R.40 }\end{array}$ & $\begin{array}{l}\text { of Cooperation } \\
\text { PC }\end{array}$ & $\begin{array}{l}\text { - Expressly provide for the possibility of exchange of confidential } \\
\text { information at FIU level. }\end{array}$ \\
\hline \multicolumn{3}{|c|}{ Other relevant AML/CFT measures or issues } \\
\hline $\begin{array}{c}\text { Resources an } \\
\text { R.30 } \\
\text { R.32 }\end{array}$ & $\begin{array}{l}\text { Statistics } \\
\text { LC } \\
\text { LC }\end{array}$ & $\begin{array}{l}\text { - Maintain statistics on criminal procedure seizures and confiscations and } \\
\text { more comprehensive statistics on seizure and confiscation of criminal } \\
\text { proceeds. }\end{array}$ \\
\hline
\end{tabular}

Compliant (C): the Recommendation is fully observed with respect to all essential criteria.

Largely compliant (LC): there are only minor shortcomings, with a large majority of the essential criteria being fully met.

Partially compliant (PC): the country has taken some substantive action and complies with some of the essential criteria.

Non-compliant (NC): there are major shortcomings, with a large majority of the essential criteria not being met.

Not applicable (NA): a requirement or part of a requirement does not apply, due to the structural, legal or institutional features of a country.

\section{H. Authorities' Response}

The Liechtenstein authorities would like to thank the evaluators for their professional work and the huge amount of time they have invested in Liechtenstein's assessment. Their findings and impressions are reflected in a very comprehensive and detailed report. The valuable discussions and feedback with respect to the Liechtenstein AML/CFT system will help Liechtenstein to further improve its AML/CFT system.

Liechtenstein was assessed for the first time by the IMF in 2002. The IMF observed a high level of compliance with international standards for anti-money laundering and combating the financing of terrorism, particularly the standards issued by the FATF. Since then, Liechtenstein has continued to make serious and significant efforts to strengthen the regime to prevent money laundering and terrorist financing. Various laws have been amended or even totally revised, like for example the Due Diligence Act (DDA). The DDA applies to every financial institution and DNFBP in Liechtenstein. The Financial Market Authority is the single regulator that is responsible to supervise every financial institution and DNFBP. 
Both, money laundering and the financing of terrorism are criminalized and to a large extent in line with international standards. Liechtenstein has set up a very proactive reporting system in the last years, which has led to the detection of various high profile cases in the fight against money laundering and the financing of terrorism. In addition, this proactive approach has made it possible in the last years to set up close and mutually beneficial relationships with foreign authorities and international organizations in the AML/CFT sector.

Liechtenstein will continue to further strengthen its established and successful AML/CFT system based on the findings of this report. Some of the recent recommendations have already been implemented, i.e. mutual legal assistance in cases of VAT tax fraud as per July 27, 2007, or are in progress. The EU Directive 2005/60/EC (Third EU AML/CFTDirective) and the Directive 2006/70/EC (laying down implementing measures for Directive 2005/60/EC) are planned to be implemented in 2008. Thus, many of the current recommendations will be met. In addition, the implementation of the EU Regulation No. 1781/2006 on information on the payer accompanying transfers of funds (with regard to wire-transfer) is going to lead to full compliance with SR VII. Furthermore, the implementation of a disclosure system in order to fulfill the required measures of SR IX concerning physical cross-border transportation of currency and bearer negotiable instruments is - due to the customs union in collaboration with Switzerland - already in progress.

Liechtenstein will pursue the chosen way of strengthening its AML/CFT system and strive thereby for a sustainable implementation of international standards. 